\title{
Analysis of Potentially Mobile Phosphorus in Arable Soils Using Solid State Nuclear Magnetic Resonance
}

\author{
R. W. McDowell,* L. M. Condron, N. Mahieu, P. C. Brookes, P. R. Poulton, and A. N. Sharpley
}

\begin{abstract}
In many intensive agroecosystems continued inputs of phosphorus (P) over many years can significantly increase soil $P$ concentrations and the risk of $P$ loss to surface waters. For this study we used solid-state ${ }^{31} \mathrm{P}$ nuclear magnetic resonance (NMR) spectroscopy, highpower decoupling with magic angle spinning (HPDec-MAS) NMR, and cross polarization with magic angle spinning (CP-MAS) NMR to determine the chemical nature of potentially mobile $P$ associated with aluminum (AI) and calcium (Ca) in selected arable soils. Three soils with a range of bicarbonate-extractable Olsen $P$ concentrations

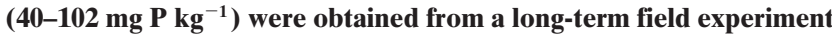
on continuous root crops at Rothamsted, UK, established in 1843 (sampled 1958). This soil has a threshold or change point at $59 \mathrm{mg}$ Olsen $P \mathrm{~kg}^{-1}$, above which potentially mobile $P$ (as determined by extraction with water or $0.01 M \mathrm{CaCl}_{2}$ ) increases much more per unit increase in Olsen $P$ than below this point. Results showed that $\mathbf{C a C l}_{2}$ and water preferentially extracted Al-P and Ca-P forms, respectively, from the soils. Comparison among the different soils also indicated that potentially mobile $P$ above the threshold was largely present as a combination of soluble and loosely adsorbed (protonated-cross polarized) $\mathbf{P}$ forms largely associated with $\mathrm{Ca}$, such as monetite $\left(\mathrm{CaHPO}_{4}\right)$ and dicalcium phosphate dihydrate $\left(\mathrm{CaHPO}_{4} \cdot \mathbf{2 H}_{2} \mathrm{O}\right)$, and some Al-associated $P$ as wavellite. The findings of this study demonstrate that solid-state NMR has the potential to provide accurate information on the chemical nature of soil $P$ species and their potential mobility.
\end{abstract}

$\mathrm{E}$ XCESSIVE FERTILIZER USE can lead to phosphorus (P) concentrations in topsoil that exceed those required for optimum plant growth and increase the risk of $\mathrm{P}$ movement to surface waters and possible environmental damage by eutrophication. The use of soil $\mathrm{P}$ data for environmental purposes represents an important step in the development of recommendations for farmers and policy makers (Sharpley and Tunney, 2000). An innovative environmental approach to data analysis involves using a split-line model to determine a soil $\mathrm{P}$ threshold (change point or break point) to assess potential P loss. This separates the relationship between soil test $\mathrm{P}$ and $\mathrm{P}$ in subsurface or overland flow into two sections, one with greater $\mathrm{P}$ loss per unit increase in soil $\mathrm{P}$ concentration than the other (McDowell et al., 2001; McDowell and Sharpley, 2001). McDowell and Sharpley (2001) showed that a plot of $0.01 \mathrm{M} \mathrm{CaCl}_{2}$-extractable

R.W. McDowell and A.N. Sharpley, USDA-ARS Pasture Systems and Watershed Management Research Laboratory, University Park, PA 16802-3702. L.M. Condron, Soil, Plant \& Ecological Sciences Division, P.O. Box 84, Lincoln University, Canterbury, New Zealand. N. Mahieu, Department of Chemistry, Queen Mary, University of London, London E1 4NS, UK. P.C. Brookes and P.R. Poulton, IACR, Rothamsted, Harpenden, Hertfordshire AL5 2JQ, UK. R.W. McDowell, present address: AgResearch Limited, Invermay Agricultural Centre, Private Bag 50034, Mosgiel, New Zealand. Received 2 June 2000. *Corresponding author (richard.mcdowell@agresearch.co.nz).

Published in J. Environ. Qual. 31:450-456 (2002).
$\mathrm{P}\left(\mathrm{CaCl}_{2}-\mathrm{P}\right)$ or water-extractable $\mathrm{P}$ against soil test $\mathrm{P}$ was similar to a plot of $\mathrm{P}$ loss in subsurface flow and overland flow, respectively. They suggested that $\mathrm{CaCl}_{2}-$ and water-extractable P could act as substitutes for subsurface or overland flow P loss data to predict an environmentally based threshold in soil test $\mathrm{P}$.

Data from soil sorption and solubility equilibrium studies have demonstrated that $\mathrm{P}$ accumulates in soils largely in association with a combination of aluminum (Al), iron $(\mathrm{Fe})$, and calcium $(\mathrm{Ca})$ (Barrow, 1999; Lindsay, 1979). However, only direct analysis of soil using techniques such as nuclear magnetic resonance (NMR) spectroscopy can identify the nature of solid-phase $\mathrm{P}$ and its influence on P solubility (Frossard et al., 1994; Hinedi and Chang, 1989). Hinedi et al. (1992) showed that the sorption of $\mathrm{P}$ by $\mathrm{CaCO}_{3}$ at rates between 3.33 and $36.72 \mu \mathrm{mol} \mathrm{P}$ sorbed $\mathrm{g}^{-1} \mathrm{CaCO}_{3}$ formed an apatitelike phase and brushite $\left(\mathrm{CaHPO}_{4} \cdot 2 \mathrm{H}_{2} \mathrm{O}\right)$ that was detectable with ${ }^{31} \mathrm{P}$ cross polarization with magic angle spinning (CP-MAS) NMR. Cross polarization NMR detects $\mathrm{P}$ in the immediate vicinity of protons $(\mathrm{H})$. Lookman et al. (1997) used this technique to show that the pool of $\mathrm{P}$ extracted by a hydrous-ferric oxide $\mathrm{P}$ sink (defined as a fast P-pool supplying soil solution) was present in acid sandy soil at a chemical shift of 1.16 $\mathrm{ppm}$. This was attributed to a readily soluble $\mathrm{Ca}-\mathrm{P}$ phase (not condensed) or "loosely" absorbed (protonated) P.

Here we present data for soils from plots of the longterm Barnfield experiment at Rothamsted, Harpenden, UK (Warren and Johnston, 1962). The soils cover a wide range of Olsen $\mathrm{P}$ and $\mathrm{CaCl}_{2}-\mathrm{P}$ concentrations (13 to $163 \mathrm{mg} \mathrm{P} \mathrm{kg}^{-1}$ and 0.06 to $1.00 \mathrm{mg} \mathrm{P} \mathrm{L}^{-1}$, respectively) and exhibit a threshold or change point at $59 \mathrm{mg}$ Olsen $\mathrm{P} \mathrm{kg}^{-1}$ (Fig. 1; McDowell et al., 2001). The objective of this study was to investigate the chemical nature of potentially mobile $\mathrm{P}$ using solid-state ${ }^{31} \mathrm{P}$ NMR in three soils from the Barnfield experiment with Olsen P concentrations that are less than, equal to, and greater than the determined threshold in soil test P.

\section{MATERIALS AND METHODS}

\section{Soils}

Archived soil samples were obtained from the long-term experiment on continuous root crops at Rothamsted Experimental Station, Hertfordshire, UK. This experiment, established in 1843 on an argillic brown earth soil (Typic Hapludalf), includes treatments with different levels of mineral fertilizer

Abbreviations: $\mathrm{CaCl}_{2}-\mathrm{P}$, phosphorus extractable by $0.01 M \mathrm{CaCl}_{2}$ CP-MAS, cross polarization with magic angle spinning; DCPD, dicalcium phosphate dihydrate $\left(\mathrm{CaHPO}_{4} \cdot 2 \mathrm{H}_{2} \mathrm{O}\right) ; \mathrm{HA}$, hydroxyapatite $\left[\mathrm{Ca}_{10^{-}}\right.$ $\left.\left(\mathrm{PO}_{4}\right)_{6}(\mathrm{OH})_{2}\right]$; HPDec-MAS, high-power decoupling with magic angle spinning; NMR, nuclear magnetic resonance; OCP, octacalcium phosphate $\left[\mathrm{Ca}_{8} \mathrm{H}_{2}\left(\mathrm{PO}_{4}\right)_{6} \cdot 5 \mathrm{H}_{2} \mathrm{O}\right]$. 


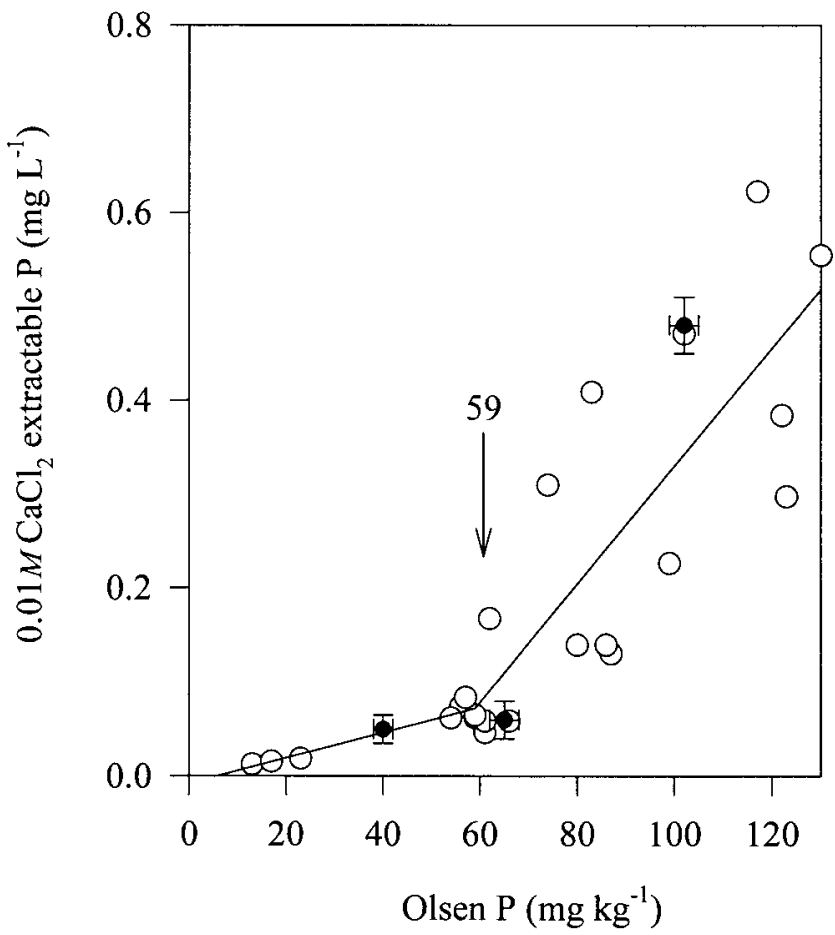

Fig. 1. The relationship between Olsen $\mathbf{P}$ and $\mathrm{CaCl}_{2}-\mathrm{P}$ for Barnfield soils from the 1958 sampling (adapted from McDowell et al., 2001). The arrow indicates the threshold or change point at $59 \mathrm{mg}$ Olsen $\mathbf{P} \mathbf{~ k g}^{-1}$. Filled circles indicate the samples used here $( \pm$ standard errors).

and organic manure inputs (Warren and Johnston, 1962). Results from an earlier study carried out by McDowell et al. (2001) on samples taken from the Barnfield experiment in 1958 revealed a threshold of $59 \mathrm{mg}$ Olsen $\mathrm{P} \mathrm{kg}^{-1}$. Based on these results, three topsoil $(0-23 \mathrm{~cm})$ samples were taken from the 1958 sampling that were below, at, and above the determined threshold. These were selected for closer examination in the present study (Table 1). The soils were air-dried and ground to $<2 \mathrm{~mm}$ at the time of sampling. Although these soils are in excess of $30 \mathrm{yr}$ old, recent evidence suggests that few physiochemical changes have occurred during this time (Blake et al., 2000).

Three replicate extractions with Olsen's reagent (bicarbonate at $\mathrm{pH} 8.5)$ and $0.01 \mathrm{M} \mathrm{CaCl}_{2}$ were performed using a soil to solution ratio of 1:20 (Olsen et al., 1954) and 1:5 $\left(\mathrm{CaCl}_{2}-\mathrm{P}\right)$, respectively. Both extractions employed a shaking time of 30 min before filtration $(<0.45 \mu \mathrm{m})$ and $\mathrm{P}$ determination by the method of Murphy and Riley (1962). Total P was measured following soil digestion with a concentrated $\mathrm{HCl}$ and $\mathrm{HNO}_{3}$ mix (3:1 v/v) (Crosland et al., 1995). Soil pH was measured in water using a 1 to 2.5 soil to solution ratio.

Total $\mathrm{Al}, \mathrm{Fe}$, and $\mathrm{P}$ in acid ammonium oxalate extracts (McKeague and Day, 1966) of water- and $\mathrm{CaCl}_{2}$-extracted soils and unextracted control soils (each soil treatment extracted in triplicate) were determined by inductively couple plasma spectrometry. Organic carbon (C) was determined by ignition (Grewal et al., 1991).

In order to remove potentially mobile $\mathrm{P}$ the soils were sequentially extracted 10 times with either water or $0.01 \mathrm{M}$ $\mathrm{CaCl}_{2}$ using a soil to solution ratio of $1: 5$ and a shaking time of $30 \mathrm{~min}$. Samples were centrifuged $(2600 \times \mathrm{g})$ for $10 \mathrm{~min}$ before the supernatant was discarded and new extractant added. Following extraction, soils were air-dried prior to solidstate ${ }^{31} \mathrm{P}$ NMR analysis.
Table 1. Selected mean chemical characteristics of Barnfield arable soils.

\begin{tabular}{lccc}
\hline Characteristic & Soil 1 & Soil 2 & Soil 3 \\
\hline pH & $7.3(>0.1) \dagger$ & $7.1(>0.1)$ & $7.2(>0.1)$ \\
Organic C, $\mathrm{g} \mathrm{kg}^{-1}$ & $22(1)$ & $29(1)$ & $25(1)$ \\
Total P, mg kg & $1470(6)$ & $1940(12)$ & $2100(7)$ \\
\hline
\end{tabular}

$\dagger$ Numbers in parentheses represent the standard error of the mean.

Statistical analyses (mean and standard error) for Olsen $\mathrm{P}$, $\mathrm{CaCl}_{2}-\mathrm{P}$, total $\mathrm{P}$, and $\mathrm{pH}$ were performed using SPSS Version 10.0 (SPSS, 1999). A one-way analysis of variance using Tukey's HSD test was performed on ammonium oxalateextractable $\mathrm{P}, \mathrm{Al}$, and $\mathrm{Fe}$ concentrations presented in Table 3.

\section{Solid-State Phosphorus-31 High-Power Decoupling with Magic Angle Spinning and Cross Polarization with Magic Angle Spinning Nuclear Magnetic Resonance}

Solid-state ${ }^{31} \mathrm{P}$ high-power decoupling with magic angle spinning (HPDec-MAS) and cross-polarization with magic angle spinning (CP-MAS) NMR spectra were obtained using a Bruker (Rheinstetten, Germany) MSL 300 operating at 121.5 $\mathrm{MHz}$. The HPDec-MAS experiment excites all nuclei nonselectively while the CP-MAS experiment consists of the transfer of polarization from the ${ }^{1} \mathrm{H}$ nuclei to the ${ }^{31} \mathrm{P}$ nuclei. Samples for each soil (Olsen $\mathrm{P}$ concentration) and treatment were combined and ground to $<150 \mu \mathrm{m}$ before being packed into 4-mm zirconia rotors with Kel-F caps (3M, Minneapolis, MN) and spun at 6.5 to $10 \mathrm{kHz}$. For both experiments a repetition rate of $500 \mathrm{~ms}$ was used. Depending upon the sample, between 43000 and 105000 scans were accumulated (6 to $15 \mathrm{~h}$ ) for HPDec-MAS and between 46000 and 418000 scans (6 to $58 \mathrm{~h}$ ) for CP-MAS with a contact time of $1 \mathrm{~ms}$. Chemical shifts $(\delta \mathrm{ppm})$ were determined relative to external $85 \%$ orthophosphoric acid $\left(\mathrm{H}_{3} \mathrm{PO}_{4}\right)$.

Spectra were deconvoluted into the signals listed with possible assignments in Table 2 using the Bruker Winfit program. We assumed a Gaussian lineshape for all the peaks. The peaks for the spinning sidebands were based on the center bands using the "ss band" model of the program. All the resulting signals were integrated. The signal intensity associated with $\mathrm{Al}$ and $\mathrm{Ca}$ species were summed and expressed as a percentage of the total observed signal intensity to give total percent Al-P and Ca-P in the spectra (Table 3). To make the data semiquantitative, signals for Al-P and Ca-P species were ex-

Table 2. Nuclear magnetic resonance (NMR) peak assignments (chemical shift) used to define the sum total of Al-P and Ca-P species.

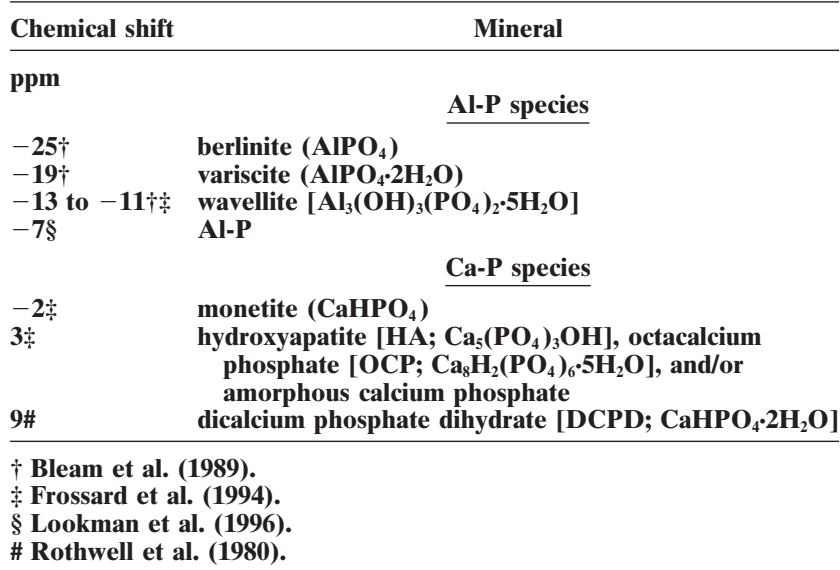


Table 3. Mean oxalate-extractable elements (P, Al, and Fe) and the sum of Al-P and Ca-P deconvoluted species (high-power decoupling with magic angle spinning nuclear magnetic resonance [HPDec-MAS NMR]) in each soil before extraction (control) and after extraction with $0.01 M \mathrm{CaCl}_{2}$ or water.

\begin{tabular}{|c|c|c|c|c|c|c|}
\hline Soil and treatment & $\mathbf{P}_{\text {ox }} \dagger$ & $\mathbf{A l}_{\text {ox }}$ & $\mathbf{F e}_{\text {ox }}$ & Al-P & Ca-P & Ca-P to Al-P ratio \\
\hline & \multicolumn{3}{|c|}{$\longrightarrow \operatorname{mmol~kg}^{-1} \longrightarrow$} & \multicolumn{2}{|c|}{ \% } & \\
\hline 1 Control & 47 & 1609 & 703 & 36 & 64 & 1.78 \\
\hline $0.01 M \mathrm{CaCl}_{2}$ & 43 & 1134 & 567 & 22 & 78 & 3.53 \\
\hline Water & 72 & 2537 & 1158 & 29 & 71 & 2.45 \\
\hline 2 Control & 63 & 1364 & 637 & 39 & 61 & 1.56 \\
\hline $0.01 M \mathrm{CaCl}_{2}$ & 60 & 1832 & 846 & 15 & 85 & 5.67 \\
\hline Water & 50 & 1433 & 668 & 28 & 72 & 2.57 \\
\hline 3 Control & 65 & 1460 & 646 & 16 & 84 & 5.25 \\
\hline $0.01 M \mathrm{CaCl}_{2}$ & 54 & 467 & 275 & 10 & 90 & 9.00 \\
\hline Water & 46 & 826 & 420 & 45 & 55 & 1.22 \\
\hline
\end{tabular}

† All treatments for each soil were significantly different from one another for each oxalate extractable element using Tukey's HSD test.
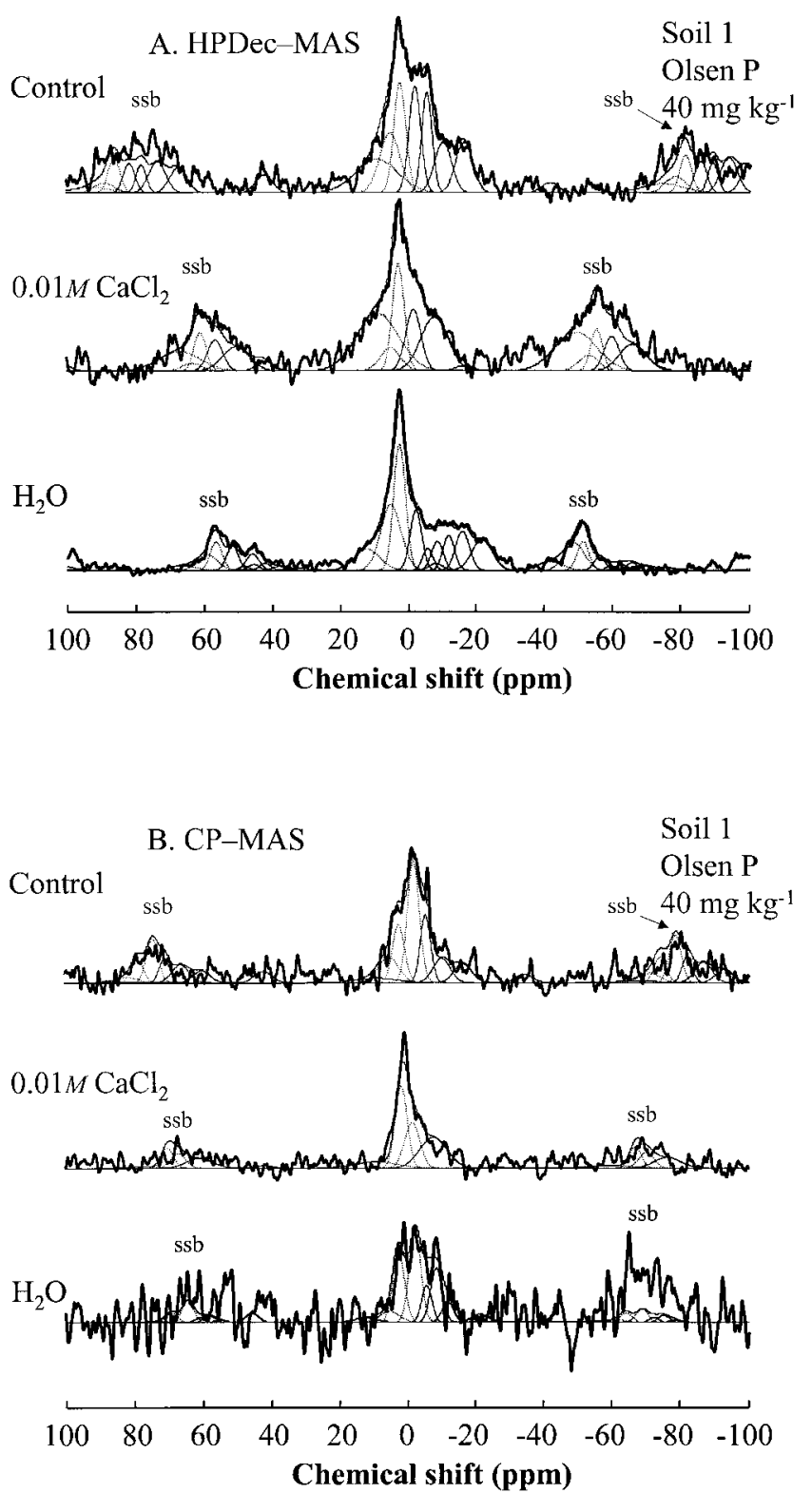

Fig. 2. High-power decoupling with magic angle spinning (HPDecMAS) nuclear magnetic resonance (NMR) $(A)$ and cross polarization with magic angle spinning (CP-MAS) $(B)$ spectra of Soil 1 before extraction (control) and after extraction with either $0.01 M$ $\mathrm{CaCl}_{2}$ or water. Dashed and solid peaks represent $\mathrm{Ca}-\mathrm{P}$ and $\mathrm{Al}-\mathrm{P}$ species, respectively (see Fig. 3, Table 2). Resonances marked ssb are spinning sidebands. pressed relative to acid ammonium oxalate-extractable $\mathrm{Al}$, $\mathrm{Fe}$, and $\mathrm{P}$ in each soil, assuming that $\mathrm{Fe}$ and $\mathrm{Al}$ have the same affinity for P on a molar basis (Lookman et al., 1996). As the $\mathrm{pH}$ values of the selected Barnfield soils were similar (Table 1) any variability due to the changing hydration status of $\mathrm{Al}$ or Fe with $\mathrm{pH}$, and therefore affinity, is minimal. Much work has also shown that oxalate-extractable $\mathrm{Al}$ and $\mathrm{Fe}$ selectively extract $\mathrm{P}$ that is active in determining soil solution $\mathrm{P}(\mathrm{R}$. Lookman, personal communication, 1995). However, it is acknowledged that the data generated should be interpreted with caution due to variability in assigning $\mathrm{P}$ species to peaks within the spectra.

Since Fe-associated $\mathrm{P}$ is not visible by solid state ${ }^{31} \mathrm{P} \mathrm{HPDec}-$ MAS NMR, Fe-P was calculated from the ratio of oxalateextractable Fe to $\mathrm{Al}$ and $\mathrm{P}$ (Lookman et al., 1996). For example, for Control Soil 2, Ca-P/Al-P = 1.56 (deduced from deconvolution data, Table 3) and $\mathrm{Fe}_{\mathrm{ox}} / \mathrm{Al}_{\mathrm{ox}}=0.467$ (derived from acid ammonium oxalate extraction, Table 3). Substituting Ca-P and $\mathrm{Al}-\mathrm{P}$ in the equation $\mathrm{P}=\mathrm{Ca}-\mathrm{P}+\mathrm{Al}-\mathrm{P}+\mathrm{Fe}-\mathrm{P}$ and solving for Al-P gives:

$$
\begin{aligned}
\mathrm{Al}-\mathrm{P}= & \left\{62.9\left[\mathrm{P} \mathrm{mmol} \mathrm{kg}{ }^{-1}\right] /[1.56(\mathrm{Ca}-\mathrm{P} / \mathrm{Al}-\mathrm{P})+1\right. \\
& \left.\left.+0.467\left(\mathrm{Fe}_{\text {ox }} / \mathrm{Al}_{\mathrm{ox}}\right)\right]\right\} \times 30.97 \mathrm{~g} \mathrm{~mol}^{-1} \\
\mathrm{Al}-\mathrm{P}= & 641 \mathrm{mg} \mathrm{P} \mathrm{kg}^{-1}, \mathrm{Fe}-\mathrm{P}=0.467 \\
& \times 641 \mathrm{mg} \mathrm{P} \mathrm{kg}^{-1},
\end{aligned}
$$

and

$$
\mathrm{Ca}-\mathrm{P}=1.56 \times 641 \mathrm{mg} \mathrm{P} \mathrm{kg}{ }^{-1}
$$

Thus, for Soil 2, Al-P + Ca-P (derived from deconvoluted and acid ammonium oxalate extraction data) $=1648 \mathrm{mg} \mathrm{kg}^{-1}$ and Fe-P $=300 \mathrm{mg} \mathrm{kg}^{-1}$. Berlinite, integrated to represent $7.8 \%$ of total spectra $\left(1648 \mathrm{mg} \mathrm{kg}^{-1}\right)$ then calculates to have a concentration of $128 \mathrm{mg} \mathrm{kg}^{-1}$.

\section{RESULTS AND DISCUSSION}

The three Barnfield soils selected for this study cover range of soil $\mathrm{P}$ concentrations and exhibit a threshold in Olsen $\mathrm{P}$ concentration at $59 \mathrm{mg} \mathrm{kg}^{-1}$ (Fig. 1; McDowell et al., 2001). Thus, Soil 2 (65 mg Olsen $\left.\mathrm{P} \mathrm{kg}^{-1}\right)$ was close to the threshold concentration, while Soil 3 (102 $\mathrm{mg}$ Olsen $\mathrm{P} \mathrm{kg}^{-1}$ ) and Soil 1 (40 $\mathrm{mg}$ Olsen $\mathrm{P} \mathrm{kg}^{-1}$ ) were above and below the threshold concentration, respectively (Fig. 1; Table 1).

The HPDec-MAS and CP-MAS NMR spectra for Soils 1, 2, and 3 are shown in Fig. 2, 3, and 4. The associated signal designation and semiquantitative data are presented in Tables 2, 3, and 4. Data indicated that the types and relative signal intensities of $\mathrm{P}$ species identified in each soil in the HPDec-MAS and CP-MAS 


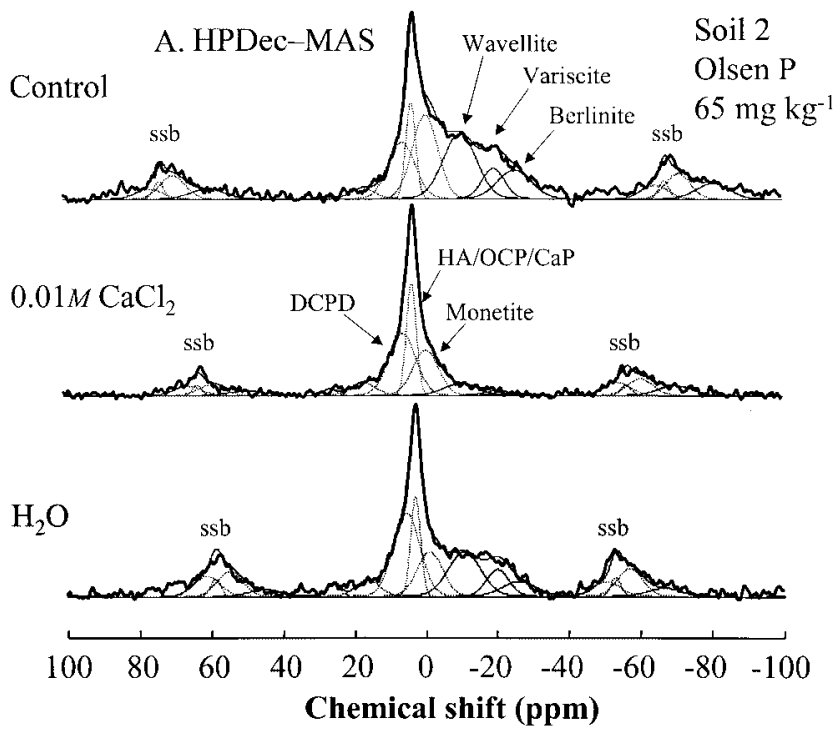

B. CP-MAS
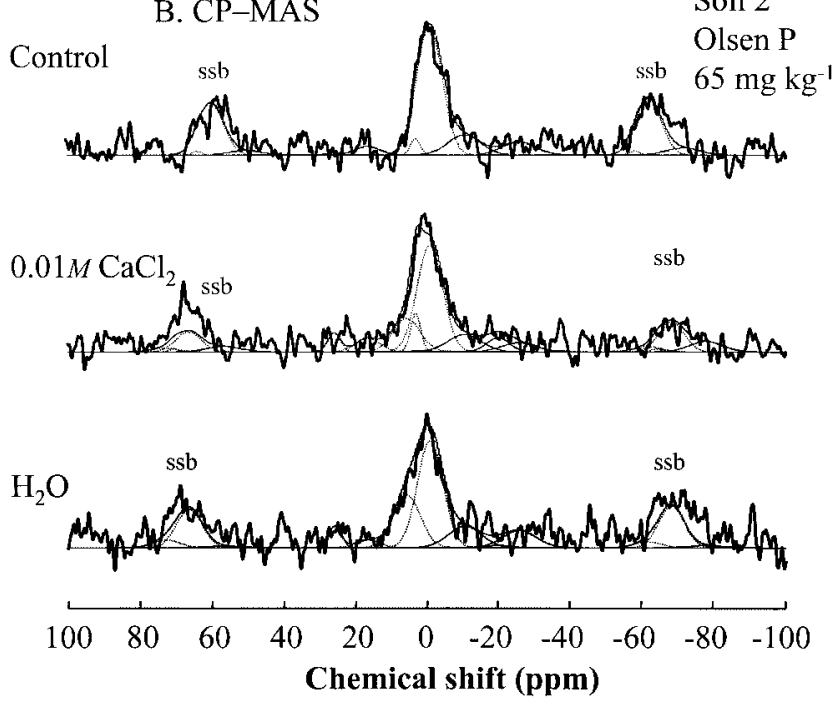

Fig. 3. High-power decoupling with magic angle spinning (HPDecMAS) nuclear magnetic resonance (NMR) $(A)$ and cross polarization with magic angle spinning $(\mathrm{CP}-\mathrm{MAS})(B)$ spectra of Soil 2 before extraction (control) and after extraction with either $0.01 M$ $\mathrm{CaCl}_{2}$ or water. Dashed and solid peaks represent $\mathrm{Ca}-\mathrm{P}$ and $\mathrm{Al}-\mathrm{P}$ species, respectively. Resonances marked ssb are spinning sidebands.

spectra were different (Fig. 2-4 and Table 4). The spectra generated by HPDec-MAS had higher signal to noise ratios than those generated by CP-MAS (Fig. 2-4). Accordingly, the number of scans required to generate an adequate definition of peaks in the CP-MAS spectra was generally three times greater than required for HPDec-MAS spectra.

\section{High-Power Decoupling with Magic Angle Spinning Experiment}

Based on data from HPDec-MAS spectra most P was associated with $\mathrm{Ca}$ (Table 3 ). Overall, the greatest

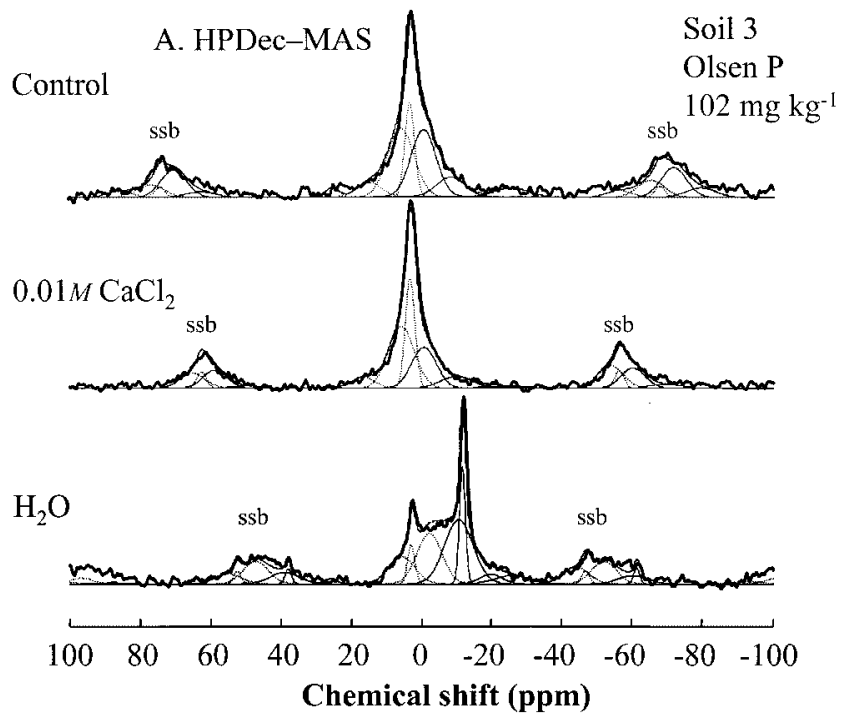

B. CP-MAS

Soil 3
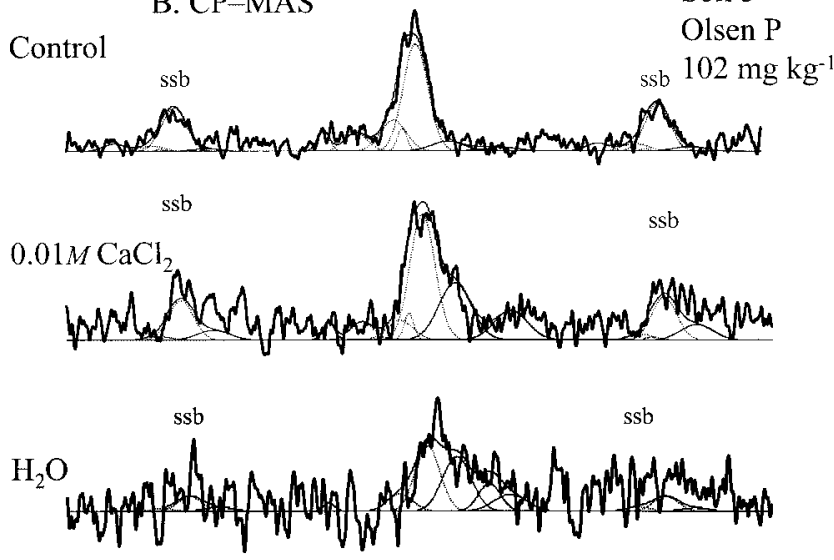

$$
\begin{array}{ccccccccccc}
100 & 80 & 60 & 40 & 20 & 0 & -20 & -40 & -60 & -80 & -100 \\
\text { Chemical shift (ppm) }
\end{array}
$$

Fig. 4. High-power decoupling with magic angle spinning (HPDecMAS) nuclear magnetic resonance (NMR) $(A)$ and cross polarization with magic angle spinning (CP-MAS) $(B)$ spectra of Soil 3 before extraction (control) and after extraction with either $0.01 M$ $\mathrm{CaCl}_{2}$ or water. Dashed and solid peaks represent Ca-P and Al-P species, respectively (see Fig. 3a, Table 2). Resonances marked ssb are spinning sidebands.

signal intensities among the Al-P and Ca-P species in the control (unextracted) soils were tentatively attributed to wavellite, monetite, dicalcium phosphate dihydrate $\left(\mathrm{CaHPO}_{4} \cdot 2 \mathrm{H}_{2} \mathrm{O} ; \mathrm{DCPD}\right)$, and hydroxyapatite $\left[\mathrm{Ca}_{10}\left(\mathrm{PO}_{4}\right)_{6}(\mathrm{OH})_{2} ; \mathrm{HA}\right]$-octacalcium phosphate $\left[\mathrm{Ca}_{8} \mathrm{H}_{2}\right.$. $\left.\left(\mathrm{PO}_{4}\right)_{6} \cdot 5 \mathrm{H}_{2} \mathrm{O} ; \mathrm{OCP}\right]$ (Table 4).

Concentrations of the different $\mathrm{P}$ species shown in Table 4 were calculated from the percentage of the total spectra they occupied (i.e., the sum total of Al-P and $\mathrm{Ca}-\mathrm{P}$ species). This would not include $\mathrm{P}$ associated with paramagnetics (e.g., $\mathrm{Fe}$ - or $\mathrm{Mn}$-associated $\mathrm{P}$ ), which is calculated by difference from acid ammonium oxalate extraction and included in the Fe-P designated pool in Table 4. 
Table 4. Percentages of high-power decoupling with magic angle spinning (HPDec-MAS) spectra and cross polarization with magic angle spinning (CP-MAS) spectra (in italic type) allocated to $\mathbf{P}$ forms in each soil before extraction (control) and after extraction with $0.01 M \mathrm{CaCl}_{2}$ or water.

\begin{tabular}{|c|c|c|c|c|c|c|c|c|c|}
\hline \multirow[b]{2}{*}{ Probable solid phase } & \multicolumn{3}{|c|}{ Soil 1} & \multicolumn{3}{|c|}{ Soil 2} & \multicolumn{3}{|c|}{ Soil 3} \\
\hline & Control & $0.01 M \mathrm{CaCl}_{2}$ & Water & Control & $0.01 M \mathrm{CaCl}_{2}$ & Water & Control & $0.01 M \mathrm{CaCl}_{2}$ & Water \\
\hline \multicolumn{10}{|l|}{ Al-P compounds } \\
\hline \multirow[t]{3}{*}{ Berlinite } & 2.8 & - & 7.8 & 7.8 & 0.7 & 4.4 & 3.3 & 1.0 & 3.2 \\
\hline & 8.9 & - & 2.7 & 5.5 & 3.9 & 6.4 & 1.6 & 9.2 & 9.2 \\
\hline & (35) & - & (84) & $(127) \dagger$ & (11) & (60) & (64) & (16) & (36) \\
\hline \multirow{3}{*}{ Variscite } & 8.5 & - & 6.9 & 5.5 & 1.3 & 5.4 & 0.1 & 0.7 & 2.4 \\
\hline & 12.7 & - & - & - & 4.0 & 0.6 & 0.6 & - & 10.2 \\
\hline & (107) & - & (75) & (91) & (22) & (74) & (2) & (10) & (28) \\
\hline \multirow{3}{*}{ Wavellite } & 6.2 & - & 6.2 & 25.6 & 12.6 & 17.9 & 12.5 & 8.7 & 39.4 \\
\hline & - & - & 6.2 & 13.1 & 14.1 & 9.6 & 7.0 & 25.4 & 29.8 \\
\hline & (78) & - & (66) & (422) & (219) & (246) & (234) & (137) & (431) \\
\hline \multirow{3}{*}{ Amorphous Al-P } & 7.4 & 22.1 & 5.1 & - & - & - & - & - & - \\
\hline & - & 30.0 & 16.4 & - & - & - & - & - & - \\
\hline & (93) & (261) & (55) & - & - & - & - & - & - \\
\hline \multirow{3}{*}{ Other $\mathbf{A l}-\mathbf{P}$} & 11.4 & - & 3.4 & - & - & - & - & - & - \\
\hline & 14.3 & - & 9.8 & - & - & - & - & - & - \\
\hline & (144) & - & (36) & - & - & - & - & - & - \\
\hline \multicolumn{10}{|l|}{ Ca-P compounds } \\
\hline \multirow[t]{3}{*}{ Monetite } & 18.2 & 15.1 & 12.1 & 29.3 & 27.0 & 25.4 & 34.2 & 28.6 & 30.9 \\
\hline & 30.1 & 25.5 & 30.8 & 75.4 & 50.1 & 58.0 & 60.3 & 48.8 & 38.8 \\
\hline & (231) & (180) & (130) & (482) & (469) & (349) & (642) & (451) & (355) \\
\hline \multirow{3}{*}{$\begin{array}{l}\text { Ha, OCP, or } \\
\text { intermediate }\end{array}$} & 17.7 & 16.7 & 22.6 & 11.0 & 19.2 & 12.4 & 12.3 & 19.6 & 5.8 \\
\hline & 15.0 & 32.7 & 21.5 & - & 5.6 & - & 3.3 & 3.0 & 10.2 \\
\hline & (224) & (199) & $(243)$ & (182) & (334) & (171) & (231) & (309) & (67) \\
\hline \multirow[t]{3}{*}{ DCPDI } & 17.3 & 7.3 & 23.2 & 18.5 & 33.5 & 29.6 & 28.4 & 27.3 & 17.4 \\
\hline & 15.0 & - & 21.5 & - & 14.4 & 20.3 & 14.1 & 7.3 & - \\
\hline & (219) & (87) & $(250)$ & (304) & (581) & (406) & (534) & (428) & (199) \\
\hline \multirow{3}{*}{ Other Ca-P } & 10.7 & 38.7 & 12.9 & 2.3 & 5.8 & 4.9 & 9.3 & 4.2 & 0.7 \\
\hline & 3.5 & 1.7 & 3.2 & 3.0 & 7.3 & 3.0 & 13.0 & 6.2 & 1.8 \\
\hline & (134) & (460) & (137) & (38) & (100) & (66) & (173) & (66) & (8) \\
\hline $\mathrm{Fe}-\mathrm{P}$ & (200) & (131) & (144) & (300) & (117) & (177) & (132) & (106) & (263) \\
\hline
\end{tabular}

$\dagger$ Numbers in parentheses are concentrations ( $\mathrm{mg} \mathrm{P} \mathrm{kg}^{-1}$ soil) of $\mathbf{P}$ forms after deconvolution of the ${ }^{31} \mathbf{P}$ HPDec-MAS NMR spectra.

$\$$ Other $=$ undefined but likely Al-P or Ca-P species.

$\S \mathrm{HA}$, hydroxyapatite $\left[\mathrm{Ca}_{10}\left(\mathrm{PO}_{4}\right)_{6}(\mathrm{OH})_{2}\right] ;$ OCP, octacalcium phosphate $\left[\mathrm{Ca}_{8} \mathrm{H}_{2}\left(\mathrm{PO}_{4}\right)_{6} \cdot 5 \mathrm{H}_{2} \mathrm{O}\right]$.

II DCPD, dicalcium phosphate dihydrate $\left(\mathrm{CaHPO}_{4} \cdot 2 \mathrm{H}_{2} \mathrm{O}\right)$.

In general, the number of $\mathrm{P}$ species detected was similar in soils following extraction with water or $0.01 M$ $\mathrm{CaCl}_{2}$, except in Soil 1 where berlinite, variscite, wavellite, and peaks designated as "Other-unknown" Al-P species were absent in the spectra of the soil extracted with $0.01 \mathrm{M} \mathrm{CaCl}_{2}$ (Fig. 1; Table 4).

The quantities of $\mathrm{P}$ extracted by either water or 0.01 $\mathrm{M} \mathrm{CaCl}_{2}$ were different. Distribution of signal intensities and calculated concentrations among $\mathrm{Ca}-\mathrm{P}$ and $\mathrm{Al}-\mathrm{P}$ forms changed markedly following extraction with either $0.01 M \mathrm{CaCl}_{2}$ or water. Results presented in Table 3 indicate that $0.01 \mathrm{M} \mathrm{CaCl}_{2}$ preferentially extracted $\mathrm{Al}-$ associated $\mathrm{P}$, while water favored $\mathrm{Ca}$-associated $\mathrm{P}$. The extraction of Al-P species is clearly evident in the NMR spectra (not to scale) of extracted soil by the loss of peaks from -4 to $-25 \mathrm{ppm}$ (Fig. 2, 3, and 4). In the soil below the threshold concentration (Soil 1), $0.01 \mathrm{M}$ $\mathrm{CaCl}_{2}$ completely extracted all Al-P forms, except a peak defined by Lookman et al. (1996) as corresponding to amorphous Al-P. This amorphous Al-P increased in concentration possibly due to some resorption or redistribution of Al-P forms during extraction. In the other two soils (Soils 2 and 3, at and above the threshold concentration), $0.01 \mathrm{M} \mathrm{CaCl}_{2}$ did not completely extract any Al-P species. No Al-P species were completely extracted by water in any soil and many increased in concentration (Table 4), most likely due to its preferential extraction of $\mathrm{Ca}-\mathrm{P}$ species (increasing the percentage of the spectra occupied by Al-P species) and possible resorption or redistribution of $\mathrm{P}$ forms.

Concentrations of Fe-P showed no apparent relationship with either Al-P or Ca-P forms. Concentrations of Fe-P were consistently smaller following extraction with $0.01 \mathrm{M} \mathrm{CaCl}_{2}$ compared with water (Table 4), which suggests that $\mathrm{Fe}-\mathrm{P}$ in these soils was more soluble in $0.01 \mathrm{M} \mathrm{CaCl}_{2}$.

\section{Cross-Polarization Experiment}

Data from the HPDec-MAS NMR presented in Tables 2 and 4 show that in each soil the ratio of Ca-P to Al-P increased following extraction with $\mathrm{CaCl}_{2}$ and water (Table 3), and that the magnitude of increases was greater for $0.01 \mathrm{M} \mathrm{CaCl}_{2}$ than water extracted soils, consistent with preferential removal of Al-P. On the other hand, the Ca-P to Al-P ratio decreased following extraction of Soil 3 with water (Table 3), which indicates preferential extraction of $\mathrm{Ca}-\mathrm{P}$ relative to $\mathrm{Al}-\mathrm{P}$ or the resorption of $\mathrm{P}$ during extraction. Resorption would tend to favor $\mathrm{P}$ that is less soluble in water, such that $\mathrm{Al}-$ and $\mathrm{Fe}-\mathrm{P}$ species were preferentially formed during extraction relative to the control soil. Evidence from CP-MAS spectra indicates that Al-P species present after water extraction in Soil 3 are characterized by $\mathrm{P}$ in close association with protons, representing $\mathrm{P}$ that is loosely sorbed.

Semiquantitative data calculated from HPDec-MAS 
spectra indicated that while much $\mathrm{P}$ is extracted from both $\mathrm{Al}-$ and $\mathrm{Ca}-\mathrm{P}$ species, as Olsen $\mathrm{P}$ concentration increases from Soil 2 to 3 only $\mathrm{Ca}-\mathrm{P}$ species such as monetite and DCPD increase while Al-P species do not. For example, an increase in Olsen $\mathrm{P}$ from near the threshold $\left(65 \mathrm{mg} \mathrm{kg}^{-1}\right)$ to well in excess of the threshold $\left(102 \mathrm{mg} \mathrm{kg}^{-1}\right)$ was associated with increases in monetite (33\%), HA-OCP (27\%), and DCPD (76\%), while many of the Al-P species and Fe-P did not (e.g., the concentration of wavellite was greater in the unextracted Soil 2 than Soil 3; Table 4). Data from the CP-MAS spectra indicate that following extraction, the greatest loss of signal intensity was caused by decreases in monetite and DCPD, while the signal intensity of HA-OCP was essentially unchanged and some Al-P species and Fe-P actually increased (Table 4). This suggests that much of the P extracted is loosely sorbed, not condensed, protonated Ca-P. Similarly, Lookman et al. (1997) used $\mathrm{CP}-\mathrm{MAS}$ to show that soil $\mathrm{P}$ rapidly desorbed to water was attributable to a loosely adsorbed or protonated $\mathrm{Ca}-\mathrm{P}$ species. Clearly, these $\mathrm{Ca}-\mathrm{P}$ species play a significant role in the release of $\mathrm{P}$ and the quantity-intensity relationship that exists between soil test $\mathrm{P}$ (Olsen $\mathrm{P}$ ) and either water or $\mathrm{CaCl}_{2}$-extractable $\mathrm{P}$.

For neutral to alkaline soils there is much literature to support the influence of $\mathrm{Ca}$ on $\mathrm{P}$ dynamics and transformations with concentration. For example, Holford and Mattingly (1975) studied $\mathrm{P}$ adsorption by 24 calcareous soils (including some of the same soils used here) using a two-surface Langmuir equation, where it is assumed that adsorption occurs on two different surfaces of low or high energy. High-energy adsorption surfaces were closely related to dithionite-soluble Fe, while the low-energy adsorption sites were highly correlated with the surface area of $\mathrm{CaCO}_{3}$ and organic matter content, but not with total $\mathrm{CaCO}_{3}$ content. This shows that (i) $\mathrm{P}$ is less strongly bound to $\mathrm{CaCO}_{3}$ surfaces and more readily released to soil solution than if bound to hydrous oxides, and (ii) the sorption-desorption reactions of $\mathrm{P}$ with the soil are a function of surface area.

Stumm and Leckie (1971) and Avnimelech (1980) found that insoluble $\mathrm{Ca}-\mathrm{P}$ species such as hydroxyapatite (HA) form via the transformation of $\mathrm{Ca}$ phosphates of intermediate solubility as surface complexes. Similarly, Hinedi et al. (1992) showed that the sorption of P onto $\mathrm{CaCO}_{3}$ was characterized by the formation of HA and at higher $\mathrm{P}$ concentrations by the formation of brushite in association with HA. In a heterogeneous system such as soil in contact with solution, the sorption and desorption of $\mathrm{P}$ can be seen as a precursor for heterogeneous precipitation or dissolution (Sparks, 1995). In our study, it is likely that the quantity-intensity relationship and threshold in Olsen $\mathrm{P}$ of the Barnfield soils can be attributed to the buildup of more soluble P species, such as monetite and DCPD as surface complexes associated with less soluble Ca-P compounds (e.g., HA-OCP) that act as precursors. Thus, as Olsen $\mathrm{P}$ concentrations increase, so does the concentration of the competition for $\mathrm{P}$ fixation sites on the surface of these species. This causes loosely sorbed compounds to form (e.g., DCPD) and increases $0.01 \mathrm{M} \mathrm{CaCl}_{2}$ - and water-extractable $\mathrm{P}$ much more relative to Olsen $\mathrm{P}$, which dissolves a different pool of soil P (exchangeable with bicarbonate).

\section{PERSPECTIVE}

We do not wish to suggest that Ca-P species are the sole cause of the quantity-intensity relationship and threshold. Moreover, the data also show that Al-P species such as wavellite play an important role; also $\mathrm{CP}$ MAS data indicate that some $\mathrm{P}$ is probably solubilized during extraction and reforms as amorphous Al-P or wavellite (e.g., Soil 1 in Table 4). Similarly, we cannot discount the role of Fe-P, and although distinct Fe-P precipitates are unlikely to form at the $\mathrm{pH}$ of our soils (Pierzynski et al., 1990), extraction by water and 0.01 $M \mathrm{CaCl}_{2}$ did decrease its concentration. Consequently, we stress that the release of $\mathrm{P}$ from our soils comes from a continuum of $\mathrm{P}$ species, whereby the most soluble and easily released are extracted by water or $0.01 \mathrm{M} \mathrm{CaCl}_{2}$ (e.g., desorption before dissolution). Our data indicates that $\mathrm{P}$ lost from the Barnfield arable soils is from both Al-P and Ca-P species, but most likely as monetite, DCPD, and wavellite in the soils at or in excess of the threshold in Olsen $\mathrm{P}$ for this soil type.

The data presented here represent an example of one soil type and similar management conditions. McDowell et al. (2001) presented examples of how the quantityintensity relationship changes in different soil types and management conditions, and especially with changing $\mathrm{pH}$. For instance, in the Park Grass experiment (also at Rothamsted, UK), the soils have a wide range of $\mathrm{pH}$ from approximately 3.8 to 7.8 . When a quantity-intensity relationship is plotted for these soils, two thresholds can be determined: one for soils $<$ pH5.8 and one for soils above this $\mathrm{pH}$. Other work has shown that in the quantity-intensity relationship of Olsen $\mathrm{P}$ against $\mathrm{CaCl}_{2}-\mathrm{P}$, $\mathrm{CaCl}_{2}-\mathrm{P}$ is highly correlated to $\mathrm{Al}-$ and $\mathrm{Fe}-\mathrm{P}$ concentration in acidic soils and to Al-P and $\mathrm{Ca}-\mathrm{P}$ in the soils with pH >5.8 (McDowell and Condron, 2000).

There are many examples in the literature of quantity-intensity relationships that emphasize either the potential for P uptake (as in a sorption isotherm) or P loss (as shown here). Methods for generating these relationships vary from a simple plot of soil test $\mathrm{P}$ against $\mathrm{P}$ in overland flow to plots of $\mathrm{P}$ saturation against $\mathrm{P}$ in drainage waters (R. Lookman, personal communication, 1995; McDowell et al., 2001). However, no one technique can yet predict, on a chemical basis, when the potential for increased P loss (i.e., a threshold) will occur. As we have demonstrated here, no one species is solely responsible for P loss, consequently if a universal predictor for $\mathrm{P}$ loss is to be determined then it must be able to account for the differential solubility of the many $\mathrm{P}$ forms that exist in soil.

\section{CONCLUSIONS}

The results have demonstrated that extracting low, medium, and high $\mathrm{P}$ concentration soils with $0.01 \mathrm{M}$ $\mathrm{CaCl}_{2}$ and water preferentially extracted Al-P and Ca-P forms, respectively. Comparing $\mathrm{P}$ forms between each soil before and after extraction showed that potentially mobile $\mathrm{P}$ in the soil above the threshold was largely present as a combination of soluble and loosely adsorbed (protonated-cross polarized) $\mathrm{P}$ forms associated 
with $\mathrm{Ca}$, principally as monetite $\left(\mathrm{CaHPO}_{4}\right)$ and DCPD $\left(\mathrm{CaHPO}_{4} \cdot 2 \mathrm{H}_{2} \mathrm{O}\right)$. Some $\mathrm{P}$ extracted was also associated with $\mathrm{Al}$ in the form of wavellite. This study demonstrates that solid-state NMR has the potential to improve the definition of soil $\mathrm{P}$ species and their potential mobility.

\section{ACKNOWLEDGMENTS}

Funding for this study was provided by the United Kingdom Biotechnology and Biological Sciences Research Council (Grant AO 6462). The solid-state ${ }^{31} \mathrm{P}$ NMR spectroscopy was carried out at University College London (in association with Dr. A.E. Aliev) as part of the University of London Intercollegiate Research Scheme.

\section{REFERENCES}

Avnimelech, Y. 1980. Calcium-carbonate-phosphate surface complex in calcareous systems. Nature 288:255-257.

Barrow, N.J. 1999. The four laws of soil chemistry: The Leeper lecture 1998. Aust. J. Soil Res. 37:787-829.

Blake, L., K.W.T. Golding, C.J.B. Mott, and P.R. Poulton. 2000. Temporal changes in chemical properties of air-dried stored soils and their intrepretation for long-term experiments. Eur. J. Soil Sci. 51: 345-353.

Bleam, W.F., F.E. Pfeffer, and J.S. Frye. 1989. ${ }^{31} \mathrm{P}$ solid-state nuclear magnetic resonance spectroscopy of aluminium phosphate minerals. Phys. Chem. Miner. 16:455-464.

Crosland, A.R., F.J. Zhao, S.P. McGrath, and P.W. Lane. 1995. Comparison of aqua-regia digestion with sodium-carbonate fusion for the determination of total phosphorus in soils by inductively coupled plasma-atomic emission-spectroscopy (ICP). Commun. Soil Sci. Plant Anal. 26:1357-1368.

Frossard, E., P. Tekely, and J.Y. Grimal. 1994. Characterization of phosphate species in urban sewage sludges by high-resolution solidstate ${ }^{31}$ P NMR. Eur. J. Soil Sci. 45:403-408.

Grewal, K.S., G.D. Buchan, and R.R. Sherlock. 1991. A comparison of three methods of organic carbon determination in some New Zealand soils. J. Soil Sci. 42:251-257.

Hinedi, Z.R., and A.C. Chang. 1989. Solubility and phosphorus-31 magic angle spinning nuclear magnetic resonance of phosphorus in sludge-amended soils. Soil Sci. Soc. Am. J. 53:1057-1061.

Hinedi, Z.R., S. Goldberg, A.C. Chang, and J.P. Yesinowski. 1992. $\mathrm{A}^{31} \mathrm{P}$ and ${ }^{1} \mathrm{H}$ MAS NMR study of phosphate sorption onto calcium carbonate. J. Colloid Interface Sci. 152:141-160.

Holford, I.C.R., and G.E.G. Mattingly. 1975. The high- and low- energy phosphate adsorbing surfaces in calcareous soils. J. Soil Sci. 26:407-417.

Lindsay, W.L. 1979. Chemical equilibria in soils. Wiley-Interscience, New York.

Lookman, R., H. Geerts, P. Grobet, R. Merckx, and K. Vlassak. 1996 Phosphate speciation in excessively fertilized soil: $\mathrm{A}{ }^{31} \mathrm{P}$ and ${ }^{27} \mathrm{Al}$ MAS NMR spectroscopy study. Eur. J. Soil Sci. 47:125-130.

Lookman, R., P. Grobert, R. Merckx, and W.H. van Riemsdijk. 1997. Application of ${ }^{31} \mathrm{P}$ and ${ }^{27} \mathrm{Al}$ MAS NMR for phosphate speciation studies in soil and aluminum hydroxides: Promises and constraints. Geoderma 80:369-388.

McDowell, R.W., and L.M. Condron. 2000. Chemical nature and potential mobility of phosphorus in fertilized grassland soils. Nutr. Cycling Agroecosyst. 57:225-233.

McDowell, R.W., and A.N. Sharpley. 2001. Approximating phosphorus release from soils to surface runoff and subsurface drainage. J. Environ. Qual. 30:508-520.

McDowell, R.W., A.N. Sharpley, P.C. Brookes, and P.R. Poulton. 2001. Relationship between soil test phosphorus and phosphorus release to solution. Soil Sci. 166:137-149.

McKeague, J.A., and J.H. Day. 1966. Dithionite and oxalate-extractable $\mathrm{Fe}$ and $\mathrm{Al}$ as aids in differentiating various classes of soils. Can. J. Soil Sci. 46:13-22.

Murphy, J., and J.R. Riley. 1962. A modified single solution method for the determination of phosphate in natural waters. Anal. Chim. Acta 27:31-36.

Olsen, S.R., C.V. Cole, F.S. Watanabe, and L.A. Dean. 1954. Estimation of available phosphorus in soils by extraction with sodium bicarbonate. USDA Circ. 939. U.S. Gov. Print. Office, Washington, DC.

Pierzynski, G.M., T.J. Logan, and S.J. Traina. 1990. Phosphorus chemistry and mineralogy in excessively fertilized soils: Solubility equilibria. Soil Sci. Soc. Am. J. 54:1589-1595.

Rothwell, W.P., J.S. Waugh, and J.P. Yesinowski. 1980. High-resolution variable-temperature ${ }^{31} \mathrm{P}$ NMR of solid calcium phosphates. J. Am. Chem. Soc. 102:2637-2643.

Sharpley, A.N., and H. Tunney. 2000. Phosphorus research strategies to meet agricultural and environmental challenges of the 21st century. J. Environ. Qual. 29:176-181.

Sparks, D.L. 1995. Environmental soil chemistry. Oxford Univ. Press, New York.

SPSS. 1999. SPSS Version 10.0. SPSS, Chicago, IL.

Stumm, W., and J.O. Leckie. 1971. Phosphate exchange with sediments; its role in the productivity of surface waters. p. 26/1-26/16. In Proc. 5th Int. Conf. Adv. Water Pollut. Res. Vol. III. Pergamon, Oxford.

Warren, R.G., and A.E. Johnston. 1962. Barnfield. p. 227-247. In Report of Rothamsted Experimental Station for 1961. Lawes Agricultural Trust, Harpenden, UK. 